torical studies into American university librarianship. Too frequently, it seems, we are making decisions without concern for the fact that the same problems have been faced many times before. In this regard it may be well to note that no historical or comparative look at academic libraries can avoid experience in other countries than our own. Even Wilson and Tauber look toward Europe only briefly when discussing trends in library education. That rich History of the Bodleian Library by Sir Edmund Craster, for example, ought to be read carefully by every American university librarian. As a professional group we are curiously non-historical and monolingual.

Another difficulty, it seems to this reviewer, that we face in discussing the university library in this country stems from inadequate information about the university that it serves. Wilson and Tauber touch on this in an early chapter, and they wisely recognize that local university administrative experience will basically effect the tendency in the local library. Discussions of the varying relationship of professional school libraries to the central library administration, for example, might be more fruitful if considered openly in the light of the varying relationship of professional schools and their deans to the central university administration. However, the average librarian learns about university power politics only through experience. But where else to learn? Our American university presidents are generally reticent about discussing the theory and practice of university education and administration. Consequently, in this country we unfortunately have no journal with the scope and dignity of the British Universities Quarterly.

The literature of librarianship, is, however, becoming extensive. This, coupled with the variety of practice and the frequency which practice changes, makes occasional syntheses essential. Library Trends was born recently because of this need. Wilson and Tauber answer the need for the whole broad field of American academic librarianship. What they set out to do they have done with clarity and thoroughness as we would expect of them. -Robert Vosper, University of Kansas Libraries.

\section{Mass Communication}

The Process and Effects of Mass Communication. Edited by Wilbur Schramm. Urbana: University of Illinois Press, 1954, $586 \mathrm{p}$.

Not long after beginning the reading of this volume a strong sense of having been over all of this ground before stimulated recall of the fact that the same editor and the same press had produced two previous anthologies of material in the general field of mass communication. A question about the need for a third one came naturally to mind and precipitated a re-examination of the two earlier volumes. The question proved to be not easily answered and led finally to a fairly detailed analysis of the content of all three volumes under four different criteria. A succinct summary of that analysis proving elusive, it is presented here as possibly constituting evidence of the extent of progress in the field of communication research and thinking during a six-year period.

The first volume edited by Mr. Schramm, published in 1948 and entitled Communication in Modern Society, differs from the other two in that the authors included came together and participated in the Illinois Institute of Communications Research. "Out of this conference grew the papers" in the 1948 anthology. Those 15 papers were thus original writing at that particular point in time.

The second of these florilegia edited by Mr. Schramm was entitled Mass Communications and was published in 1949. It is a more conventional anthology of pieces previously published in books and journals and brought together as " $a$ book of readings selected and edited for the Institute of Communications Research in the University of Illinois," and tied together with a small amount of original connective tissue written by the editor. The volume presently under review follows this latter pattern with a somewhat greater amount of connective tissue.

Early writing in a new field quite normally and usually takes the form of the essay. It is made up of speculations as the result of thinking on the part of the author; all of this as opposed to the reporting of objective and empirical research. As a field develops the essay type of writing tends to decrease 
TABLE I

Proportion of Essays and Research in Three Schramm Volumes

\begin{tabular}{|c|c|c|c|c|c|}
\hline \multirow{2}{*}{$\begin{array}{c}\text { Publication } \\
\text { Date }\end{array}$} & \multicolumn{2}{|c|}{ Essays } & \multicolumn{2}{|c|}{ Research } & \multirow[b]{2}{*}{$\begin{array}{l}\text { Total } \\
\text { PaGes }\end{array}$} \\
\hline & $\begin{array}{c}\text { Number of } \\
\text { Pages }\end{array}$ & Per Cent & $\begin{array}{c}\text { Number of } \\
\text { Pages }\end{array}$ & Per Cent & \\
\hline 1948 & 129 & 58.1 & 93 & 41.9 & 222 \\
\hline 1949 & 324 & 60.4 & 212 & 39.6 & 536 \\
\hline 1954 & 228 & 41.2 & 325 & 58.8 & 553 \\
\hline Total & 681 & 51.9 & 630 & 48.1 & 1311 \\
\hline
\end{tabular}

and the reporting of research tends to develop in volume and importance. Thinking these three volumes, covering a brief six-year span of time in a comparatively new field, might provide a tentative index to its development from a speculative to an emipirical science, all of the contributions to all three volumes were classified as being either essays or research. The results of that classification are shown in Table I. Assuming that the efforts of the same anthologist over a period of years are a reliable index to the nature of the writing being done in this particular field, it is immediately obvious that there has been a significant increase in the proportion of research writing in the field of communication between 1948 and 1954. This would seem to be clear gain, would seem to indicate that we are going somewhere, that we are becoming more objective in our approach to the problems of mass communication.

There is some evidence in Table II, however, that the assumption that this anthologist's work is a good index to trends in this field is unfounded. It could be that for the 1954 volume only his own progress toward a more objective viewpoint is reflected. That is, perhaps he looked harder for the research material. Certainly it is true that he went farther back in his search. Since all of the material in the 1948 volume was new as of that year and because of the special way in which it was compiled it must be left out of consideration. When the relative age of the contents of the other two volumes is examined it is found that, whereas 25.3 per cent of the contents of the 1949 anthology were more than three years old at the time of their reprinting, more than half of the contents of the 1954 anthology were that old in that

TABLE II

Distribution of Content of Three Schramm Volumes by Age

\begin{tabular}{|c|c|c|c|c|c|c|c|}
\hline \multirow[b]{2}{*}{ AGE } & \multicolumn{2}{|c|}{1948} & \multicolumn{2}{|c|}{1949} & \multicolumn{2}{|c|}{1954} & \multirow[b]{2}{*}{$\begin{array}{l}\text { Total } \\
\text { Pages }\end{array}$} \\
\hline & $\begin{array}{c}\text { NuMbER OF } \\
\text { PaGES }\end{array}$ & Per Cent & $\begin{array}{c}\text { NuMBER OF } \\
\text { PaGES }\end{array}$ & Per Cent & $\begin{array}{c}\text { Number OF } \\
\text { PaGeS }\end{array}$ & Per Cent & \\
\hline $\begin{array}{l}\text { New } \\
\text { One Year } \\
\text { Two Years } \\
\text { Three Years } \\
\text { Four to Five Years } \\
\text { Six to Ten Years } \\
\text { More Than Ten Years }\end{array}$ & 222 & 100.0 & $\begin{array}{r}69 \\
122 \\
178 \\
31 \\
34 \\
39 \\
63\end{array}$ & $\begin{array}{r}12.9 \\
22.8 \\
33.2 \\
5.8 \\
6.3 \\
7.3 \\
11.7\end{array}$ & $\begin{array}{r}41 \\
49 \\
111 \\
63 \\
108 \\
159 \\
22\end{array}$ & $\begin{array}{r}7.4 \\
8.9 \\
20.1 \\
11.4 \\
19.5 \\
28.7 \\
4.0\end{array}$ & $\begin{array}{r}332 \\
171 \\
289 \\
94 \\
142 \\
198 \\
85\end{array}$ \\
\hline Total & 222 & 100.0 & 536 & 100.0 & 553 & 100.0 & 1311 \\
\hline
\end{tabular}


TABLE III

Distribution of Content of Three Schramm Volumes by Source of Material

\begin{tabular}{|c|c|c|c|c|c|c|}
\hline \multirow{2}{*}{$\begin{array}{l}\text { Source of } \\
\text { Material }\end{array}$} & \multicolumn{2}{|c|}{1948} & \multicolumn{2}{|c|}{1949} & \multicolumn{2}{|c|}{1954} \\
\hline & $\begin{array}{c}\text { Number of } \\
\text { Pages }\end{array}$ & Per Cent & $\begin{array}{l}\text { Number of } \\
\text { PAGES }\end{array}$ & Per Cent & $\begin{array}{c}\text { Number OF } \\
\text { PageS }\end{array}$ & Per Cent \\
\hline $\begin{array}{l}\text { New Material } \\
\text { Material Reprinted from } \\
\text { Schramm ' } 48 \\
\text { Material Reprinted from } \\
\text { Schramm " } 49 \\
\text { Material Reprinted from } \\
14 \text { Books } \\
\text { Material Reprinted from } \\
19 \text { Books } \\
\text { Material Reprinted from } \\
6 \text { Journals } \\
\text { Material Reprinted from } \\
7 \text { Journals } \\
\text { Material Reprinted from } \\
\text { "Various Sources" }\end{array}$ & 222 & 100.0 & $\begin{array}{l}20 \\
34\end{array}$ & $\begin{array}{l}3.7 \\
6.3\end{array}$ & $\begin{array}{l}41 \\
15 \\
17 *\end{array}$ & $\begin{array}{l}7.4 \\
2.7 \\
0.4\end{array}$ \\
\hline Total & 222 & 100.0 & 536 & 100.0 & 553 & 100.0 \\
\hline
\end{tabular}

* Of which 15 pages are also in Schramm, 1948; hence are excluded from total and from percentage.

year. So it must be concluded that the point has not been made that progress toward greater objectivity has become discernible between the years 1949 and 1954 . We know only that in going farther back for the contents of the 1954 anthology, Mr. Schramm found or selected a larger portion of research material than was included in the 1949 volume.

Table III was developed to show the source of the material reprinted in the 1949 and 1954 florilegia. It is seen at once that material is duplicated in the three volumes to only a negligible extent. The amount of new material in 1954, all of it connective tissue of an essay character written by the editor, is twice as great as he thought it necessary to write in 1949. The proportion of material drawn from journals is considerably less in 1954 than in 1949 and the proportion drawn from books is somewhat greater. One would normally expect this progression of emphasis to be the other way around. If there is excuse for florilegia at all, it derives from the fact that they bring together into one easily accessible place a variety of material otherwise difficult to find. Since journals, by and large, are more difficult to find and use in li- braries and in personal collections, assuming they exist in the latter at all, there would seem to be more justification for bringing together the material previously published in journals than that previously published in monograph form. It could, however, very well be that the more important work in this field has been published in books rather than in journals. If this is true-and one considers the thought reluctantly-then it is also true that the science of mass communication has gone only a short way along the road towards status as a scientific discipline. For it is axiomatic now in practically all scientific fields that the more important work appears first in journals, and frequently only in journals.

The subject matter of mass communication, as considered important by Mr. Schramm at three different points in time, is shown in Table IV. The categories need only a little description to make reading of the table clear. The fourth item, communication, was used for all material which discussed three or more different kinds of communication. This explains in part why the table shows no entries at all for the field of television. Articles which discuss any two of the subjects were classified 
TABLE IV

Distribution of Content of Three Schramm Volumes by Subject

\begin{tabular}{|c|c|c|c|c|c|c|c|c|}
\hline \multirow[b]{2}{*}{ Subject } & \multicolumn{2}{|c|}{1948} & \multicolumn{2}{|c|}{1949} & \multicolumn{2}{|c|}{1954} & \multirow{2}{*}{$\begin{array}{l}\text { Total } \\
\text { Pages }\end{array}$} & \multirow{2}{*}{$\begin{array}{r}\text { Per } \\
\text { CEn? }\end{array}$} \\
\hline & $\begin{array}{c}\text { Number of } \\
\text { Pages }\end{array}$ & PER Cent & $\begin{array}{c}\text { Number of } \\
\text { Pages }\end{array}$ & PER CENT & $\begin{array}{c}\text { Number OF } \\
\text { PaGeS }\end{array}$ & Per Cent & & \\
\hline Psychology & 7 & 3.2 & 27 & 5.0 & 60 & 10.8 & 94 & 7.2 \\
\hline Propaganda & 0 & 0.0 & 14 & 2.6 & 167 & 30.2 & 181 & 13.8 \\
\hline Public Opinion & 10 & 4.5 & 29 & 5.4 & 132 & 23.9 & 171 & 13.0 \\
\hline Communication & 112 & 50.4 & 204 & 38.0 & 86 & 15.6 & 402 & 30.7 \\
\hline Effects of Comm. & 18 & 8.1 & 63 & 11.8 & 71 & 12.8 & 152 & 11.6 \\
\hline Newspapers & 48 & 21.6 & 64 & 11.9 & 17 & 3.1 & 129 & 9.8 \\
\hline Radio & 9 & 4.0 & 83 & 15.5 & 8 & 1.4 & 100 & 7.6 \\
\hline Motion Pictures & 0 & 0.0 & 44 & 8.2 & 0 & 0.0 & 44 & 3.4 \\
\hline Books & 18 & 8.1 & 6 & 1.1 & 12 & 2.2 & 36 & 2.7 \\
\hline Magazines & 0 & 0.0 & 2 & 0.4 & 0 & 0.0 & 2 & 0.2 \\
\hline Television & 0 & 0.0 & 0 & 0.0 & 0 & 0.0 & 0 & 0.0 \\
\hline Total & 222 & 100.0 & 536 & 100.0 & 553 & 100.0 & 1311 & 100.0 \\
\hline
\end{tabular}

in the subject which received the greatest amount of attention in the article.

Differences in subject emphasis among the three volumes shown in Table IV arise largely out of differing objectives at the time they were compiled. The large amount of emphasis in propaganda and public opinion in 1954, for example, is related to the author's statement of a "need for a book of background materials which could be used in training some of the [United States Information] agency's new employees in the field of research and evaluation." This also explains the greater emphasis on psychology, and explains in large part the comparatively insignificant attention paid to the several separate media of mass communication in the 1954 anthology.

This emphasis reflects very well the word "process" in the title of the book, but it seems unfortunate that so little attention could be given to the second word, "effects." For much of the writing on process becomes stultified and meaningless if we have no knowledge of the effect of that process. Furthermore, the librarian cannot help noticing that the 1954 attention to books was negligible and to magazines nonexistent. Books and magazines are still the most important, the most permanent, the most "referrable to" media of mass communication. After all, this is a book and not a radio program.

An important aspect of the content of the
1954 anthology which does not come out in the above analysis is occasioned by the volume's original intent to serve as a background for new USIA employees who would be working in the field of international communication. So it is that the final hundred pages or so are devoted to essays and research under the general heading of "Special Problems of Achieving an Effect with International Communications." The book in general, however, cannot be said to be limited to students in this broad field. As stated in Mr. Schramm's foreword, "Much of the background necessary for understanding the problems and practice of international communication is identical with the background necessary for making an intelligent approach to any other kind of social communications."

Whether such an intelligent approach is served better by an anthology than it would be by reading the fuller treatment of the original sources is a question best answered by each individual student and instructor in the field. It can be assumed that this anthology of readings will serve the educational purposes of its compiler reasonably well, or he would not have embarked on this labor of love. It is doubtful whether any other instructor in the broad field of communication will find the volume nearly so useful. Certainly this reviewer's florilegium, in the unlikely event that it is ever compiled, would contain much more research and fewer think- 
pieces, and would pay much more attention to research in the effects of particular media, especially magazines and newspapers and books, and would give much less attention to too-easy generalizations about all media.LeRoy Charles Merritt, University of California.

\section{Classified List of Reference Books and Periodicals}

The Classified List of Reference Books and Periodicals for College Libraries. W. Stanley Hoole, editor. 3d ed. Atlanta, Ga.: Southern Association of Colleges and Secondary Schools, Commission on Colleges and Universities, 1955 . xi, 227p. \$3.

In 1940 at the suggestion of the then Commission on Institutions of Higher Education of the Southern Association of Colleges and Secondary Schools, a group of college and university librarians of the South undertook the compilation of two checklists, one of reference books and one of periodicals, for use in checking and strengthening the collections of the libraries of member institutions. These lists were in every sense cooperative efforts, representing the pooled judgments of librarians, teachers, and subject special ists and based on a study of the curricula of representative southern institutions and an examination of existing comparable lists. The separate mimeographed editions of 1940 were revised and published as one in 1947 and now a third edition has been issued.

Still representing the needs of the four-year undergraduate college as reflected in the curricula of the colleges of the South, the new edition was compiled in the same way with the additional advantage of the knowledge gained from use of the earlier editions over many years.

As in the second edition the reference works are grouped in five major categories: General, Biological Sciences, Physical Sciences, Social Sciences, and Humanities, with further subject subdivisions under each. Strictly a reference list, general treatises are said to have been included only to supply an essential need in an area where reference books are not available. In this connection one might question the need of having in reference collections the various series in American history. However, if they are to be included, even the American Nation series, now largely out of print, why is there no mention of the New American Nation series of which a number of volumes are already published?

In any work of this nature there are bound to be differences of judgment, but for the most part the quality of selection remains high. Although anthropology is apparently little emphasized in southern colleges, it would seem that at least a directory like Thomas and Pikelis' International Directory of $A n$ thropological Institutions would be needed. And it is strange not to find such titles as the Bibliographic Index, Library Literature, Facts on File and the New York Times Index.

The deletion in this edition of subdivisions like Anthropology and Ethnology, Astronomy, and Meteorology has forced the titles in these fields into other groups where they are found only if a key word in the title provides a clue to their location through the index. The Anthropology titles are placed under Sociology, at least four Astronomy books are among the Physics titles, while seven of the titles classed under Meterology in the 1947 edition are now located in the same or revised editions under Geology. It seems doubtful that the elimination of these subdivisions has served any useful purpose.

Only a casual check was made for accuracy, but it was surprising to note the (Guide to) American Business Directories listed under Davis and again under U. S. Bureau of Foreign and Domestic Commerce, since the Public Affairs Press edition given under Davis is a reissue of the government document with substantially no change. Also, it was the Menefee and Chambers bibliography American Youth which was published in 1938; the supplement to it, Youth, Key to America's Future, by Chambers and Exton, which is listed here, was published in 1949.

The titles in the reference list now number 1,447 as against 778 in the first edition and 1,262 in the second. Symbols used in the 1947 edition to denote books for first purchase and those suitable for junior colleges have been dropped.

Periodicals, which were last given in a sep- 